\title{
Ori, Ooni: etnografando o inusitado em Ilê Ifé, Nigéria
}

Deborah de Magalhães Lima ${ }^{1}$

Nílsia Lourdes dos Santos ${ }^{2}$

Universidade Federal de Minas Gerais

Resumo: Relatamos episódios de uma pesquisa na Nigéria que mostram quão inusitada uma experiência etnográfica pode ser. Hospedadas no Palácio do Ooni de Ifé, as pesquisadoras acompanharam o Rei em sua intensa agenda social. Para o tema da pesquisa, Ori, o Rei ordenou que os babalaôs da corte recebessem as pesquisadoras. Deste relato fora do ordinário, o artigo enfatiza o potencial etnografável de qualquer trabalho de campo - não há como distinguir pesquisa de campo do resultado do campo.

Palavras-chave: etnografia; Nigéria; Iorubá; Ori; Ooni.

${ }^{1}$ Possui graduação em Ciências Biológicas pela Universidade Federal do Rio de Janeiro (1980), mestrado em Antropologia Social pela Universidade de Cambridge (1982) e doutorado em Antropologia Social pela Universidade de Cambridge (1992). É professora titular da Universidade Federal de Minas Gerais, onde coordena o Núcleo de Estudos sobre Populações Quilombolas e Tradicionais - NuQ.

2 Possui graduação em Serviço Social pela Universidade Paulista (2014). Mestranda em Antropologia da UFMG. 


\title{
Ori, Ooni: \\ ethnographing the unusual in Ilê Ifé, Nigeria
}

\begin{abstract}
Summary: We report incidents of an ethnographic research in Nigeria showing how extraordinary a field experience can be. Hosted at the Ooni Palace of Ifé, the researchers accompanied the King on his intense social agenda. For the topic of the research, Ori, the King ordered the court babalawos to receive the researchers. From this unusual account, the article emphasizes the ethnographic potential of any fieldwork - there is no way to distinguish work in the field from result of the field.
\end{abstract}

Keywords: ethnography; Nigeria; Yoruba; Ori; Ooni.

\section{Ori, Ooni: etnografando lo inusual en Ilê Ifé, Nigeria}

\begin{abstract}
Resumen: Reportamos episodios de una encuesta etnográfica en Nigeria que muestran cuán inusitada puede ser una experiencia de campo. Alojadas en el Palacio del Ooni de Ifé, las investigadoras acompañaron al Rey en su intensa agenda social. Para el tema de la investigación, Ori, el Rey ordenó a los babalaós de la corte que recibieran a las investigadoras. Desde esta cuenta inusual, el artículo enfatiza el potencial etnográfico de cualquier trabajo de campo: no hay forma de distinguir investigación en el campo de resultado de campo.
\end{abstract}

Palabras clave: etnografía; Nigeria; Yoruba; Ori; Ooni. 
$\mathrm{N}$ este artigo, nós duas, Deborah e Nílsia, alternamos nossas falas para relatar uma experiência de campo inusitada na cidade de Ilê Ifé, na Nigéria. O tema da pesquisa de campo foi Ori. Literalmente "cabeça" em iorubá, Ori é uma noção metafísica complexa, que trata, resumidamente, do destino, da vivência espiritual, da individualidade e da ancestralidade. Embora seja o mais importante orixá no panteão tradicional iorubá, no Brasil o Ori não é muito conhecido. No Candomblé está associado ao ritual do borí, principalmente ao que antecede a iniciação ao orixá, quando se diz "fazer a cabeça do santo". 3 Comparado à extensão da literatura sobre os orixás, é raro encontrar trabalhos sobre Ori em português.

No entanto, quase não falamos aqui sobre Ori, tema da dissertação de Nílsia. Focamos a experiência do campo. A exposição por revezamento permitiu dispensar a criação de uma fala intermediária, provavelmente impessoal e anódina, e deixou que cada uma falasse a seu modo. Eu, Deborah, havia escrito um esqueleto e Nílsia preencheu longos trechos de forma muito expressiva. Vi que não teria como escrever por cima do seu relato sem comprometer o vigor da sua fala. Decidi, então, prosseguir a escrita de modo intercalado. Assim, no que se segue, não houve preocupação com a ordem, nem com a extensão das falas. O que sobressai é o contraste, que permite notar qual das duas está falando. De sobra, o arranjo explicitou o caráter individual de toda percepção etnográfica. No meu caso, minha formação acadêmica compromete ambas, a escrita e a vivência do campo. Nílsia é do Axé. É Iyalodè, Ifadará Nílsia d'Oxum, sacerdotisa da comunidade tradicional de terreiro Ilè Asé Aségun Itesiwajú Aterosun, iniciada no culto aos orixás há 40 anos. Em 2019 iniciou o mestrado em Antropologia na UFMG, sob minha orientação. Neste texto ela não é nem a sacerdotisa, muito severa, nem a mestranda, igualmente austera, mas Nílsia, de fala espontânea. Temos quase a mesma idade; ela foi para a Nigéria com 61 anos, lá completou 62; e eu tinha 60. Desde seu ingresso no mestrado me ofereci para lhe acompanhar em campo, por um lado para facilitar a realização da tal etnografia - um tanto misteriosa para quem vem de outras áreas, no seu caso Serviço Social - mas principalmente porque eu tinha interesse em conhecer a Nigéria e podia ir. Em campo, minha participação na sua pesquisa foi maior do que eu esperava. Pensei em fazer uma pesquisa paralela, imaginei estudar a presença do dinheiro nos rituais, mas, como ficará claro, o Ori e o Ooni, além do fato de ter assumido o papel de tradutora em tempo integral, me levou - nos levou - a realizar a pesquisa juntas. No final, meu aprendizado sobre Ori me deixou mais bem qualificada para orientar uma Iyalodè.

Estivemos na Nigéria entre janeiro e fevereiro de 2019. O planejamento da viagem tomou um rumo inesperado quando, em junho de 2018, o monarca de Ilê Ifé e líder espiritual do povo iorubá, o Ooni Oba Adeyeye Babatunde Ogunwusi, esteve no Brasil pela primeira vez e incluiu Belo Horizonte no seu roteiro. Nessa ocasião, o Ooni e sua comitiva visitaram um único santuário tradicional na cidade, justamente o Ilê de Nílsia. ${ }^{4}$ A recepção que ela ofereceu rendeu dois frutos

3 Na Nigéria é o inverso. Depois de propiciar o Ori, não se deve abaixar a cabeça para nenhum outro orixá.

4 Registros da visita feitos pela mídia oficial do palácio podem ser vistos em: < www.youtube.com/watch?v=NzZXU$\underline{5 \mathrm{eXFo}}>\mathrm{e}<\underline{\text { www.youtube.com/watch?v=LeLNY35dTHo }}>$. Acesso em 15/6/2020. 
inesperados. O plano inicial para a logística do campo - alugar uma casa e estabelecer contatos a partir de um conhecido professor da Universidade Obafemi Awolowo em Ifé - se transformou quando na sala do banquete o Rei nos convidou para começarmos a pesquisa sobre Ori no seu palácio. O outro desdobramento foi a concessão de uma honraria para Nílsia, que deveria ir pessoalmente à Nigéria receber um título importante na corte de Ilê Ifé.

\section{As duas pesquisadoras em campo: a oyinbó pépé e a rainha Iyalodè, Iyalodè!!}

De fato, a pesquisadora havia recebido do Rei da cidade Ilê Ifé, estado de Oxum, na Nigéria, o Título de Iyalodè, ou seja, Rainha das Damas. Penso que seja uma espécie de socialite que paga um lobby para fazer parte da corte, sem saber o que é exatamente isso. Na noite anterior à tal coroação, o tradutor me informa que o Rei mandou que eu providenciasse a quantia de 500.000,00. Perguntei: "Mas isso é quanto em dólares?" Ele me responde "cerca de US\$1.600,00." Eu disse: "Como assim? Esse é todo dinheiro que eu trouxe para passar 15 dias, uma vez que já paguei a passagem aérea, paguei $\mathrm{R} \$ 10.000,00$ pelas hospedagens, traslado e alimentação. Terei que dar R\$ 6.000,oo?” Esse era o valor equivalente em agosto de 2018. Recordo-me que sapateei e disse: "Não estou pedindo título para ninguém, esse cara me oferece um título e agora tenho que pagar por ele? Amanhã não apareço lá, pode avisar". Entrei para minha suíte e fechei a porta muito brava. Suíte sim, porque estava hospedada em um dos resorts do Rei. O emissário não sabia o que dizer, ficou em silêncio. Por volta de $22 \mathrm{~h}$ esse rapaz foi chamado ao palácio para estar com o Rei. Passei boas horas da noite agitada, rezando, tentando me acalmar, e também precisando definir se entregava ou não meu único dinheirinho. Mas o emissário também já havia dito que pela manhã chegaria um homem da etnia Hauçá para trocar o dinheiro. Quando amanheceu, nos encontramos novamente na hora do café, cumprimentei e fui dizendo, "Veja bem: o que é que eu ganho com isso? Qual é a contrapartida?" Ele tentou me dizer que as pessoas daquele país pagam lobby altíssimo para fazer parte da corte e que eu seria muito beneficiada por isso. Mas eu não entendia. Até que chegou o doleiro. Entreguei meu rico dinheirinho e fiquei com apenas US\$100,00. Recebi uma sacola de supermercado cheia de blocos de dinheiro sujo, horrível. Eu disse: "Não vou sair pela rua carregando essa sacolinha plástica com esse tanto de dinheiro". Ele pegou pacientemente o dinheiro, colocou em sua pasta de executivo e lá fomos nós. Fato é que o meu dinheiro foi totalmente distribuído nos oito Templos pelos quais passei antes de chegar ao Palácio, acompanhada por uma multidão de gente cantando e dançando pela rua afora. É uma imagem surreal para uma ocidental.

Nessa viagem, Nílsia reviu membros da corte e autoridades religiosas que estiveram em sua casa dois meses antes. Alguns a acompanharam em sua peregrinação pelos oito templos, passando por um ritual em cada, até a cerimônia final com dezenas de babalaôs da mais alta corte, que chancelaram a sua coroação. Com o título de Iyalodè, Nílsia foi inserida na matriz relacional extremamente hierárquica dos iorubás, para os quais títulos, cargos e insígnias mobilizam trajetórias e intensas negociações interpessoais. Nem na ocasião, como ela disse, nem durante o campo chegamos a compreender bem os significados do cargo. Certamente a sua expressão monetária só aumentou a sensação de estarmos perdidas na tradução. Nas relações mais próximas era esperado que ela fizesse doações, 
como aconteceu durante a coroação. Mas no geral o título era mesmo vantajoso, facilitando o acesso a pessoas-chave para a pesquisa e nos protegendo do próprio assédio monetário - como nas abordagens dos guardas rodoviários, que param carros nas estradas para receber suborno. Conosco, quando avistavam a coroa, mandavam passar. Em vez de enfrentarmos os entraves dos serviços públicos nigerianos, Nílsia - Iyalodè Osún Worldwide, como está bordado na sua coroa de miçanga - era reverenciada por onde passava. Incluindo o aeroporto. Na viagem, sabiamente vestiu a coroa para sair do avião quando aterrissamos em Lagos e a guardou na mala de mão quando embarcamos de volta.

De minha parte, também me tornei conspícua, mas de maneira lenta. E ao contrário de Nílsia, fui "incluída fora" da matriz relacional iorubá, encaixada no protótipo de estrangeiro. Nas escalas do voo para Lagos, notei que aos poucos eu me tornava singular, até ter que me esforçar para avistar outra pessoa branca, especialmente em Ilê Ifé. Algumas mães me disseram que eu era a primeira oyinbó pépé que seus filhos conheciam - oyinbó sendo o termo de zombaria para brancos, como os ingleses que ficam vermelhos como pépé, ou pepper, quando pegam sol.

De fato, um dia após a nossa primeira aula no Templo de Ifá resolvemos ir à feira, o sol era causticante e minha orientadora não tinha guarda-sol, andava com um pano branco na cabeça, aquilo chamava ainda mais atenção, não resta dúvida de que virou atração turística. Além das crianças os adultos também faziam bullying, falavam alto, “Oiynbó pépé!", porque ela é muito branca de olhos azuis e todos queriam fazer fotos com ela. Lembrava que me sentia assim quando fui a primeira vez à Itália com meu marido; eu era a única pessoa de pele negra e todos da família me olhavam e diziam "Che bel colore!" ("Que bela cor!”).

Não foram só essas transformações. O Rei gostava de me apresentar em público como "professor from Cambridge", que obviamente não sou!, mas não lhe interessava corrigir a ligação que fez entre lugar de pós-graduação e cargo universitário. Como na corte era preciso ter título, fiquei conhecida como Prof. Por outro lado, em Ifé meu papel de orientadora de Nílsia se tornou irrelevante, pois importava mais o fato dela ser minha Iyanifá [sacerdotisa de Ifá capacitada para participar de um trecho do ritual de iniciação, conduzido por sacerdotes do sexo masculino]. Sermos de Ifá foi essencial para o campo.

Realmente foi uma inversão de papéis. Porém o fato é que antes de partirmos para Nigéria a minha orientadora fez iniciação para Ifá (culto às tradições iorubá) no meu Templo religioso na Grande Belo Horizonte, se tornando assim a minha filha de Axé. No entanto, na Universidade eu era apenas aluna e orientanda. Chegando à Nigéria, de orientadora ela passou a ser a minha pajem e eu não mais apenas a sua sacerdotisa, mas a Iyalodè do Rei. Gente, pensa uma loucura. E ali na verdade nós não éramos nada, apenas propriedades do Rei. Mas quando entrevistávamos os sacerdotes do Templo de Ifá, éramos filhas de Ifá igual aos demais ali presentes. E nós duas, orientadora e orientanda, éramos respeitadas por isso.

Quando éramos convocadas a comparecer diante do Ooni, era sempre porque tinha uma visita importante e ele queria que estivéssemos presentes. Daí era o momento das apresentações, eu era sempre apresentada como a "İyálórìsà do Brasil" e minha Orientadora era sempre apresentada como a "Professor Deborah 
de Cambridge", ela era como o grande troféu. Como sempre, ouvíamos em silêncio, porque nem rir a gente podia. Por ocasião de uma reunião com socialites na cidade de Lagos, ao me apresentar ele teve a coragem de dizer que eu sou uma famosa sacerdotisa no Brasil e que tenho milhares de seguidores nas redes sociais. Não é verdade, se tiver 250 pessoas já é muito. Na corte tem dessas coisas, mentiras sobre mentiras.

\section{De pesquisadoras a peças da corte: o nosso contexto etnográfico}

Quando a gente pensa em fazer etnografia na África, logo imaginamos: vou usar calça comprida, blusa de manga comprida, botas, chapéu de caçador, muito repelente. No nosso caso só o que se confirmou foi o repelente. Porque eu levei 12 vestidos de festa para a pesquisa, três custaram $R \$ 1.200,00$ numa loja de festas de Belo Horizonte, outros custaram $\mathrm{R} \$ 850,00$ e os demais comprei o tecido e paguei a costureira, ficaram mais em conta. De forma que quando eu abria a porta da minha suíte, eu já estava enfeitada igual a um burro de charrete. Toda maquiada e aguardando os tradicionais três toques na porta dos iorubás. Tenho absoluta certeza de que todas as mulheres daquele país dariam a vida para estar no nosso lugar. E deveriam questionar, "Por que elas?” Deveriam também se perguntar: "Por que o Rei deu esse título a uma afro-brasileira?" São perguntas sem respostas. Porque quando eu questionei o Rei por quê ele estava me dando aquele título, ele disse, "Foi Osun quem mandou". E continuei questionando, "mas você não me conhece, não sabe o quanto eu sou austera e exigente" etc. Ele respondeu "Osun te conhece e eu confio plenamente em você".

Antes de viajar, perguntei à Nílsia quantos vestidos levar, ela respondeu: “Todos que você tiver!" Não comprei vestidos novos, mas levei os de casamentos e cerimônias que tinha. A clássica reserva de roupas para o campo nem entrou na mala. Chegando em Ilê Ifé, Nílsia nos fez andar na feira atrás de um delineador, porque tinha esquecido de trazer o seu. Isso resume a essência da nossa provisão de campo, mas não caracteriza o verdadeiramente inusitado desta etnografia. Havia luxo por toda parte, não nos deixaram sofrer nenhuma das restrições comuns aos campos em lugares desprovidos - como o que víamos logo ali, do lado de fora do Palácio Real. Nossas restrições foram de outra natureza, que se resumem à sujeição ao Rei, e incluem um tipo de proposição amorosa difícil de entender.

\section{O Ooni, o grande anfitrião}

No primeiro dia em que chegamos a Ilê Ifé, fomos chamadas ao palácio para nos apresentar diante de Sua Majestade, o Rei, isso por volta de 22h. Entre tantas conversas, o Rei me perguntou: “Quanto tempo você ficará aqui?” Eu disse, "cerca de 44 dias". "Você tem disponibilidade para me acompanhar na minha agenda nestes dias?" "Claro, senhor, estou à sua disposição". Então nesse momento o Rei disse: "Quero convidar você para vir morar aqui no palácio". Um silêncio tumular tomou conta de mim. Não queria responder, mas disse: "O problema é que eu sou ocidental", para não dizer que não, que não queria obedecer às regras. $\mathrm{O}$ Rei ficou um pouco desapontado e me disse. "Vá conhecer a casa primeiro. Vocês venham, se você não gostar, vocês retornam para o resort”. Resultado, não houve opção. A casa era maravilhosa, teríamos a liberdade de fazer 
nossa própria comida, teríamos sala de jantar, sala de visita etc. O que não sabíamos é que não teríamos nenhuma privacidade, porque a todo momento ouvíamos os três toques na porta, era um súdito que dizia: "O Rei mandou chamar as senhoras". Isso era de manhã, à tarde ou tarde da noite. Porque o Rei não dorme antes das quatro da madrugada todos os dias, atendendo pessoas, e quando ele concluía que o assunto era do nosso interesse ele mandava nos buscar a qualquer hora que fosse. E o pior é que o súdito ficava de pé na sala nos aguardando, quando a gente saia em direção ao palácio, ele ia atrás nos escoltando, não tinha como não ir.

Nesse primeiro encontro, o Rei já passou a sua agenda da semana: “Amanhã receberei a visita do ex-Presidente da República, quero você presente, depois de amanhã virá o atual Vice-Presidente, depois começará o festival de Obatala e assim por diante, de forma que este palácio tem festa todos os dias”. Claro que não acreditei, porque todos os dias era muito. Claro que quebrei a cara. E assim foram todos os dias. Nunca vi uma vida social tão intensa, o Rei não conhece dia de descanso.

Mas não foi só isso. Quando, ainda cansada da longa viagem, tarde da noite fomos convocadas a comparecer diante de Sua Majestade, ele se mostrou encantado por mim, tecia elogios infindáveis, até que, em um momento, eu, brincando, disse, "Você quer casar comigo?" Bastou para isso crescer, viralizar, como se diz aqui no Brasil. Para todas as pessoas que ele me apresentava dizia que eu era a nova Oloori (esposa). Havia me feito a seguinte proposta nesse primeiro dia: "Você quer que amanhã todo mundo fique sabendo dessa notícia?" Nesse momento me restava um pouco de sensatez, respondi que não. E assim foi até quando ele quis brincar, começou a divulgar para todo mundo que eu era a sua esposa espiritual, que no ano de 1735 havíamos vivido lá e que estávamos de volta para reparar maldades cometidas e que havíamos sido grandes amantes. O assédio foi tamanho que, depois de trinta dias, passei a acreditar naquilo de verdade, achava tudo lindo, rsrsrs, comecei até fazer planos de como deixaria minha vida aqui no Brasil. No dia em que nos mudamos do resort para o palácio ele disse à minha orientadora, porque ele a envolvia também no discurso, exigindo que fosse a sua tradutora, "Não é para trazer a roupa dela do resort, é para trazer as coisas dela do Brasil". Pense numa maluquice. Quando ele viu que eu estava de fato acreditando naquilo, puxou a corda. Foi no dia em que tínhamos ido ao palácio para tratar dos preparativos do casamento. Ele desconstruiu tudo, literalmente. Disse que eu era livre para fazer o que quisesse, que poderia viajar para qualquer país do mundo e assim foi. Pense numa decepção. Chegando em casa, tarde da noite, resolvi escrever uma mensagem para ele no WhatsApp, dizendo: "Senhor, não me interessa marido espiritual, porque marido espiritual não dorme comigo, não faz sexo comigo e não paga minhas despesas”. Foi muita loucura. Daí por diante o respeito acabou. No dia em que eu não estava a fim de fazer graça para ele, esticava o braço e o dedo indicador e dizia não para ele, com sagacidade; todas as histórias que ele dizia, que ninguém podia abraçá-lo, eu dizia, "não acredito nisso, isso é balela". Ele não estava nem aí, levava tudo como se piada fosse e falava todas as bobagens que achava que deveria falar. Sua Majestade ficou longe daí por diante. Gente, tive ódio desse homem por ter me aplicado o maior 171 da minha vida, sentia vergonha, me senti arrasada, desmoralizada. Graças a Deus depois que cheguei ao Brasil tudo isso passou, tanto é que sou capaz de escrever sobre isso achando graça. Mesmo depois que voltei ele continuou por muito tempo dizendo que é meu marido. Tive que repetir para ele o mesmo código, marido espiritual... 


\section{O cotidiano do Palácio}

Uma coisa muito interessante no palácio é que você não vê mulheres circulando, a não ser na parte da manhã quando chegam as faxineiras contratadas, que ganham um salário irrisório. Limpam e vão embora. No mais, todo o trabalho é feito por homens, é incrível. Nem a rainha se vê por lá. Ela fica enfiada em sua casa dia e noite, nem as janelas abre. É o Rei quem faz todo trabalho de receber. Os seus subordinados não têm autorização para muita coisa, porque ele não delega nada, tudo passa por ele. Ele passa o tempo todo no WhatsApp. No entanto, é muito simpático com todos, indistintamente. Muito respeitoso com os idosos e carinhoso com as crianças.

No palácio era quase tudo igual todos os dias, as doninhas que faziam a faxina chegavam às vezes antes das oito da manhã e não se faziam de rogadas, iam entrando pela casa a dentro parecendo um bando de pardais em algazarra - lembrando que a nossa casa não trancava nem por dentro e nem por fora, e fora inútil pedir para consertarem; somente as portas das suítes trancavam. Trocavam os guardas das três guaritas diariamente. Pela manhã raramente o Ooni dava expediente, porque ficava até de madrugada atendendo. Às tardes sempre tinha uma festa, quando surgia gente não sei de onde para encher aquele hall, dançavam, cantavam, sorriam, não recebiam nada para comer, as crianças ganhavam algum dinheiro, depois o Rei voltava para sua sala de audiências e ia receber ilustres visitantes. Na porta do palácio sempre havia fila de pobres querendo ser atendidos, não sei ao certo quem os atendia. Uma reunião de motoristas desocupados ficava à disposição, conversando e brincando entre si no pátio, aguardando algum comando. Tinham atribuição definida quando o Rei se ausentava do palácio de carro, daí sim, seguia o comboio, uma frota de mais ou menos dez veículos de luxo. Sua Majestade às vezes saía de Rolls-Royce, outra hora de Mercedes Benz, sempre brancos.

Quando eram rituais religiosos tradicionais, Sua Majestade saía a pé cercado pela sua corte, sempre acompanhado por homens que tocavam e dançavam diante dele, e policiais do palácio, civis e federais. Tinha um que apelidamos de MacGyver, e um policial civil que andava de terno e uma pistola 380 na parte de trás da calça, coordenando a saída dos veículos. Na maioria das vezes subia no seu veículo em movimento e esperava por alguns metros antes de entrar, apenas pisando no estepe do carro e se segurando na porta, numa exibição cinematográfica. Ríamos muito dessas cenas. Ele sempre fora muito simpático com a gente. Era quem determinava em qual veículo eu e a Prof. Deborah deveríamos embarcar. Afinal de contas, nós éramos as únicas mulheres que acompanhavam o comboio do Rei.

\section{A sala do ora-veja - ora, veja!}

Esse foi o apelido que dei a uma sala de audiências no palácio, para onde eram encaminhadas todas as pessoas que teriam encontro particular com o Ooni. Ali costumávamos ficar duas, três, até quatro horas esperando para sermos recebidas por Sua Majestade. Não por solicitação nossa, e sim para atender a um chamado dele. Houve uma vez em que o Rei nos mandou ficar no resort por alguns dias, porque precisava daquela casa para hospedar uma princesa que chegaria da Inglaterra para fazer uma homenagem ao seu falecido pai. Assim, no dia aprazado nos mudamos de malas e cuias. Não tardou muito, recebi uma mensagem do Rei, 
que estava em Abuja, capital do país, dizendo que se eu não me importasse de hospedar a minha orientadora no meu quarto, não seria preciso nos mudar, ele havia dado um jeito. Só que já estávamos no resort. Agradeci, e disse que estávamos bem acomodadas. Bastou isso para que esse Rei determinasse que eu voltasse. Eu, como boa ocidental, tentava manter um diálogo democrático dizendo que estávamos bem. E não entendia que ele estava dando ordens. "Volte com suas malas imediatamente, quando eu chegar no palácio quero encontrar você lá". Mal deu tempo de ir ao quarto da minha orientadora comunicar-lhe das mensagens. Quando retornei ao meu quarto, já dei de cara com o gerente do palácio, o sr. Idowu, dizendo: "O Ooni mandou buscar a senhora, Iyalodè". Achei aquilo um absurdo, porque esse rapaz não dirige nem para ele próprio, estava se fazendo de meu motorista. Não discuti, passei a mão nas malas que, por Deus, não tinham sido desfeitas e fui para o carro. Mas logo percebi que naquele veículo as nossas malas não cabiam. Disse a ele: "Por favor, volte ao palácio, apanhe um carro com o porta-malas maior e volte para nos buscar". Foi aí que a minha orientadora, sempre muito obediente, disse: "Não! O Ooni quer encontrar a Iyalodè no palácio quando ele chegar". Conclusão: seguimos nós e deixamos as malas para serem levadas posteriormente. Do jeito que estava, eu fui, sem me trocar e muito menos colocar a tal coroa, que eu não podia me apresentar diante de Sua Majestade sem ela. Sei dizer que lá ficamos por horas. Nesse ínterim as malas chegaram, fugi, fui até nossa casa, me arrumei e voltei para a sala do ora-veja. Essa história começou por volta de 17 h no máximo, sei que já era quase meia-noite quando enviei uma mensagem à Sua Majestade lhe dizendo que estávamos aguardando. Durante esse tempo todo, na sala do ora-veja, o Rei havia atendido umas quatro pessoas. Foi quando ele viu minha mensagem e mandou que entrássemos, para dizer apenas: "I’m sorry. You can go to sleep!" [“Desculpem-me. Vocês podem ir dormir!”] Não é necessário descrever o tanto de desaforo que eu destilei para a Sua Majestade quando retornei para nossa casa naquela noite. Para mim, ele ultrapassara todos os limites do abuso de poder. Este é apenas um dos episódios de espera que vivemos durante o campo. Fazia parte da etnografia esperar. Todas as vezes que teria um evento, ou uma viagem qualquer, a gente esperava até cansar, para daí a pouco começar aquela correria; era quando o Rei aparecia e tudo tinha que acontecer subitamente. Interessante que até os súditos mais imediatos ao Rei se deitavam no tapete dessa sala e dormiam tranquilamente, enquanto a gente esperava. Era algo inexplicável!

\section{Diversos visitantes}

No palácio chegava de tudo, desde ex-presidente, vice-presidente, reitores e professores universitários, até o Príncipe Charles da Inglaterra já tinha estado lá; desde cantores pop, até mães com suas filhas para oferecer ao Rei como futuras esposas; de criancinhas de uma escola local que iam cantar para o Rei a líderes não somente iorubá, mas também das etnias de igbo até hauçá; de dançarinos tradicionais que me faziam lembrar filmes de Tarzan a músicos tocando clássicos num saxofone; enfim, o Rei é muito democrático, recebe Deus e o mundo.

Era uma bucólica noite de sexta-feira, depois de transcrever a entrevista do dia anterior, nos preparávamos para ir dormir, pois no dia seguinte às 1oh da manhã já tínhamos uma agenda com Sua Majestade em Iloko Ijesa, uma cidade vizinha, para comemorar o aniversário de 25 anos da escola Olashore International School, cujo fundador havia falecido e os alunos decidiram mesmo assim fazer a festa convidando o Ooni, que havia feito uma doação certamente de valor 
expressivo. Quando ouvimos os tradicionais três toques na porta, passava de $21 \mathrm{~h}$. Não quis acreditar, mas era verdade, lá estava o porta-voz a nos informar: "O Ooni manda chamar vocês”, não havia escolha, me troquei e lá fomos nós. A professora Deborah com uma gripe infernal, o ar-condicionado em $16^{\circ} \mathrm{C}$, lá estavam um norte-americano e dois homens hauçás, marchands, e um cineasta acompanhado por um jornalista casado com uma jornalista brasileira, que estão fazendo a mediação entre o Ooni e a prefeitura do Rio de Janeiro para montagem do Museu do Valongo, na zona portuária. Entramos. Logo pudemos entender que se tratava de uma pessoa que negocia peças arqueológicas. E o Rei estava tentando adquirir 800 peças iorubá para montar o Museu do Valongo, coisa pouca, uma bagatela de quinze milhões de dólares. Sentei-me, e por ali fiquei por horas, ouvindo aquela conversa que não me interessava. O cineasta exibiu o trailer do filme que estava produzindo, sobre a história de Pierre Verger e o povo iorubá; muito entusiasmado, certamente à procura de patrocínio. No final o Rei lhe perguntou numa cartada de mestre "E quem é que vai patrocinar isso?" Em seguida, o Ooni perguntou ao gringo qual era a peça mais cara que ele havia comprado na sua vida, mas ele desconversou e não respondeu, claro. Mas, como bom iorubá, Ooni se dirigiu falando em língua nativa aos dois hauçás, fazendo-lhes a mesma pergunta, qual foi a peça mais cara que vocês já venderam para esse gringo, eles responderam: "Uma peça de oito milhões de dólares". Nesse momento o Rei chamou Felix, seu assistente pessoal, e pediu que trouxesse algo. Não demorou muito adentrou Felix com três tigelas brancas tampadas, o Rei destampou a primeira e nos apresentou duas pedras que estavam dentro da água, pareciam cristais, eram enormes de verdade, e perguntou ao norte-americano que pedra ele achava que era. Desconfiado, o americano não podia acreditar que eram diamantes puros e brutos, em torno de $10 \mathrm{~cm}$ cada. O Rei mandou que riscasse vidro. Ele ficou a procurar por algo que pudesse testar, olhou para o relógio, mas não teve coragem. A minha orientadora, muito debochada, lhe disse para riscar "your own glasses" ("seus próprios óculos”). O homem chegou a passar a mão nos óculos, mas não deu ouvidos e continuou a procurar, até que viu uma mesa redonda de canto, não se fez de rogado e testou. Ficou boquiaberto, porque eram de verdade diamantes, ficou pasmado. O Rei dizia "isso aqui poderia acabar com a miséria da cidade”. Depois tentou exibir uma esmeralda, mas num tom de quem queria se esquivar, disse que a gema não queria sair da terrina de porcelana onde ficava guardada. Eu já não aguentava mais de tanto sono, e até então não sabia o que fazia ali. Não sei por que cargas d'água o jornalista disse algo e o Ooni lhe disse: "ah, a Iyalodè é a minha mais nova Oloori, você não sabia?" Recordo-me do olhar daquele jornalista para mim de boca aberta, pensei: "estou ferrada..."

\section{A obediência ao Rei}

Desde o dia em que tivemos que voltar ao palácio por ordem do Rei, por termos saído inocentemente sem avisar, entendemos que éramos controladas de verdade. Não queria acreditar. Daí, no dia em que entendemos que teríamos que solicitar carro e motorista se quiséssemos fazer algo diferente, que Deus e o mundo tinha que saber, optamos por alugar um carro de um parente das meninas da Comunidade de Osun e partimos em fuga para a cidade de Ibadan. Nesse dia almoçamos no restaurante, tomamos uma cerveja gelada, demos uma volta pelo shopping, compramos presentes para distribuir para as crianças por ocasião do meu aniversário, e quando retornamos ao palácio já era noite. No dia seguinte a 
façanha se repetiu, dessa vez fomos para a cidade de Ilobu, próximo à grande cidade de Osogbo. Fomos visitar um sacerdote meu amigo que já havia estado na minha casa no Brasil, porque queria fazer uma consulta com ele. Todos podem questionar, "mas você não tinha encontros com 16 sacerdotes?" Claro, mas não queria minha vida pessoal à disposição dos sacerdotes do Ooni. Foi preciso fugir. Na outra vez em que voltei a esse mesmo templo para fazer uma entrevista para a pesquisa, voltamos de forma oficial, com veículo e motorista do Rei.

A obediência ao Rei era sem comentários, todas as vezes em que nos apresentávamos diante de Sua Majestade eu me ajoelhava e colocava a cabeça no chão, sim, em sinal de respeito e submissão. E um dia em que, não sei por que razão, estávamos com ele em particular, somente eu e minha orientadora, ele parecia estar infeliz, pagou um pau para mim, retirou todos as propostas de casamento que tinha feito, na hora de sair, ele disse: "Você não vai se abaixar para o seu Rei não?” Eu não entendi, minha orientadora se abaixou e eu fiquei de pé atônita olhando para ele, ele repetiu a frase e tive que me ajoelhar, hahaha. Era muita loucura, era outro mundo, parecia que estávamos participando da gravação de um filme, hoje penso.

\section{Olusegun, Felix, Omifuntó: três diferentes esteios}

Contatos prévios e boa sorte para encontrar esteios no local fazem parte de todo campo. Uma apresentação pontual ilustra aqui a imbricação particular que se desenvolveu entre o tema da pesquisa, as condições do campo e a produção etnográfica. Já relatamos os dois eventos anteriores que explicam o convite do Rei para a hospedagem no Palácio - a visita real à casa de Nílsia e a sua coroação. Falta mencionar o esteio incidental para essa realização, Olusegun Akinruli. Outros dois esteios foram conhecidos durante o campo, Ogunleye Felix e Omifuntó. A apresentação deles, feita por Nílsia, pontua o contraste entre os nigerianos à nossa volta e introduz a narrativa de como se deu uma pesquisa de campo por ordem real.

Olusegun é a pessoa que eu cito acima na experiência da coroação. Foi meu tradutor durante minha iniciação em Ifá no ano de 2011 na cidade de Ibadan, foi o facilitador para a visita do Rei à minha casa, e foi quem me acompanhou o tempo todo na viagem de 2018. Dessa vez se limitou a nos receber no aeroporto de Lagos e nos conduzir até Ilê Ifé, certamente por ordem do Rei. Esteve por lá três vezes durante a nossa permanência, não mais que isso. Estava envolvido com seus negócios.

Felix é um rapaz muito dócil e fiel ao Rei, que nos atendia sempre que precisávamos. Ele era o cozinheiro do Rei, mas, na verdade, fazia de tudo que Sua Majestade solicitava. Ele tem uma história interessante. Antes era cozinheiro de um hotel de uma cidade da Nigéria, não sei precisar qual. E o Rei era então apenas um empresário bem-sucedido da área de construção civil que lá se hospedou, e quando Felix o viu teve um quadro de vidência em que o via sendo coroado Rei de Ilê Ifé e falou para ele. ${ }^{5}$ Depois de coroado, o Rei mandou buscar o Felix para vir morar em seu palácio. De modo que Felix é pessoa de extrema confiança do Rei, tanto que é quem cuida do Ifá do Rei, tem acesso às pedras de diamantes

\footnotetext{
$5 \mathrm{O}$ Rei foi coroado em 2015, depois de concorrer com 20 outros candidatos ao cargo, pertencentes às quatro famílias reais descendentes diretos de Oduduwa, a divindade que criou as condições de vida na terra. A seleção de Adeyeye Ogunwunsi foi feita por sacerdotes reais e consultas ao oráculo de Ifá, após a confirmação ritual da morte do Rei anterior, aos 85 anos. O Ooni tinha 40 anos e é um dos mais jovens líderes tradicionais da Nigéria.
} 
brutos que valem milhões de dólares e demais gemas preciosas etc. E sempre estava à nossa disposição todas as vezes em que o chamávamos.

Omifuntó pertence à comunidade de Osun e foi disponibilizada pela Oloori chefe maior do templo Itá Osun para nos acompanhar, porque é obrigação da Oloori Osun me assessorar, mas como ela é muito ocupada, determinou que essa moça ficasse ao nosso dispor. Na verdade, ela fazia o papel de informante. Foi extremamente útil para minha pesquisa. Nos acompanhava nas feiras, nas viagens que fazíamos às escondidas do Rei, por todos os lados. Só não ficava ao nosso lado quando a gente saia acompanhando o Rei, porque o meu lugar era junto do Rei e seus asseclas. Provavelmente essa moça foi a que mais levou dinheiro de nós. Todos os dias a gente lhe dava dinheiro. E ela não se fazia de rogada em pedir mais, sempre mais.

Era grande o contraste entre Felix e Omifuntó em relação ao dinheiro, mas não na demonstração de fidelidade. Ambos foram esteios importantes no palácio. O comportamento de Felix era marcado por sua forte inclinação mística e devoção ao Ooni. Omifuntó tinha servido o exército e encarnava um misto de guerreira e feminista. Em geral, os relacionamentos na corte têm uma forte expressão monetária. O comportamento abnegado de Felix era excepcional, enquanto Omifuntó tendia ao exagero. Desde nossa chegada, demos dinheiro para ela pagar dois meses de escola dos filhos, o aluguel, compramos um celular etc, etc.

Jamais vou esquecer essa experiência. Tudo nesse país é à base de dinheiro, desde os pequenos rituais religiosos dos quais o dinheiro faz parte, podendo até ser de modo simbólico, mas tem que ter. Até em pequenas aparições do Rei em praça pública, mesmo que essa praça seja dentro do próprio palácio, ele tem que distribuir dinheiro, para quem dança, para quem toca tambores, para quem canta, para as crianças, para um sumo sacerdote que dança... Na nossa casa, mesmo a faxineira contratada pelo palácio, já chegava perguntando "what do you have for me?" ("O que você tem para mim?") Era o motorista do palácio que nos transportava, eram pessoas que se aproximavam da gente nas ruas tocando tambor à nossa frente e nos empatando de andar, chega às raias da imoralidade. E se por ventura você precisasse deles para qualquer coisa a resposta é imediata "don't worry", eles não te ofertam nada! Depois de mais de 35 dias, aprendemos também a dizer "don't worry" ("não se preocupe").

\section{Uma pesquisa por ordem real}

Numa tarde na primeira semana de nossa estadia, após a visita do vice-presidente, o Rei determinou que fossemos nos encontrar com alguns sacerdotes em um dos salões do palácio. Mais tarde mandou cancelar o encontro e que voltássemos para a sala do ora-veja para nada, e depois de quase duas horas mandou nos conduzir de volta ao tal salão. Em seguida o Rei foi até lá se encontrar conosco e o Aragba (o chefe de todos os Sacerdotes ou babalaô da cidade de Ilê Ifé) para determinar que disponibilizasse para mim os 16 Olodus Ifá para responder a minha pesquisa. Nesse momento é que eu pude ver a importância do cargo que tinha recebido, porque, se não fosse pelo título, em hipótese alguma eu teria a oportunidade de me encontrar por várias tardes com aquelas autoridades do culto a Ifá. E numa dessas tardes o Aragba disse para os sacerdotes: "O Rei mandou que respondêssemos tudo o que a Iyalodè perguntar, não é para omitir nada”. E assim foi feito, até que eles já estavam de saco cheio da gente e o Aragba determinou que iriam encerrar tudo num só dia, seria uma bateria de manhã e à tarde, detalhe que nós não observamos e só aparecemos lá no Templo na parte da tarde, e eles 
estiveram nos aguardando a manhã toda. Foi feio.

Os 16 Olodus (Awò Olodu Merindinlogun) são os sacerdotes do Templo Mundial de Ifá, o Oke Tase de Ifé, considerado pelos iorubás como o berço da humanidade. O Aragba Agbaye, chefe Owolabi Aworeni, ocupa o cargo de autoridade mundial de Ifá. Ele e os outros Olodus obedeceram à ordem real de nos receber, mas impuseram um estilo de entrevista particular. Tínhamos hora marcada para o que chamaram de aulas - "classes" - e só respondiam a perguntas. Não faziam preleção, nem ofereciam seu saber de graça. Foi preciso pagar.

Em um dos primeiros dias no Palácio, quando ainda não tínhamos entendido o regime de hospedagem e saímos sem pedir autorização, o Ooni mandou mensagem para o motorista voltar. Na sua sala, interpelou-nos seriamente e Nílsia explicou que queríamos trocar dinheiro para dar aos Olodus. Na mesma hora o Rei mandou entregar dois grandes pacotes com notas de 500 nairas para Nílsia. Notas novinhas. Nílsia ficou constrangida. Eu disse a ela, "o Rei está financiando a sua pesquisa”.

Durante as aulas, o Aragba dizia - "ask questions" ("Faça perguntas"), e eu traduzia as perguntas de Nílsia para ele. A maioria dos babalaôs falava algum inglês, mas poucos eram fluentes. As perguntas eram traduzidas para o iorubá e as respostas, debatidas entre eles, eram depois traduzidas de volta para o inglês. Para ganhar tempo, parei de traduzir para Nílsia e passamos a estudar as gravações com Omifuntó em casa. Ela completava nos passando o que tinha ficado de fora da tradução para o inglês, e também explicava trechos mais obscuros que só com calma podíamos destrinchar.

Muitos versos do compêndio oral de Ifá são intraduzíveis porque se valem de trocadilhos e metáforas. Às vezes os babalaôs apontavam os trechos que não era possível traduzir - "traduzir é trair", disse uma vez o Aragba. Mas ali, no vai e vem entre português, inglês e iorubá, traíamos pelo menos quatro vezes... A participação de Omifuntó foi por isso providencial. Mas o problema da tradução não era só esse. O inglês dos iorubá exige uma adaptação, criando outro tipo de traição. Entre outras particularidades, o " $t$ " é pronunciado como " $d$ ". Isso me fez entender como "Mother Earth" ("Mãe Terra") um trecho que falava de modern earth - ou seja, Ile mo pe, ou aye tuntun, que quer dizer "nova terra", "terra moderna", em oposição ao tempo antigo ou aye atijo, quando os orixás chegaram à Terra. A pronúncia "moder" se referia a "modern" e não "mother"...

No último dia, apresentamos um texto impresso com 19 perguntas. Como sempre, notávamos nos babalaôs um misto de interesse em cumprir a ordem real e pressa em ficar livre da obrigação. A metodologia de pedir perguntas foi uma estratégia precisa para atender a esse fim. Eles não revelaram nada além do que lhes foi pedido. Essa foi também uma maneira de só nos oferecer o que podíamos compreender, nivelando o que nos ensinavam pelo conhecimento que nossas perguntas evidenciavam.

Mais descontraídas foram as conversas com Babalola Kolapo Ifatoogun, no Templo Ogundabede, em Ilobu. Oferecia seu saber com a erudição de uma formação familiar privilegiada. Seu falecido pai, antigo informante de Pierre Verger, instruía os filhos à noite. Em um dos encontros, Nílsia lhe fez a mesma pergunta que havia feito aos Olodus - "por que o conhecimento sobre Ori não tinha sido levado para a diáspora?” Os babalaôs tinham respondido, no melhor estilo de E. E. Evans-Pritchard, ${ }^{6}$ que "Nem todos os orixás são conhecidos na diáspora... não

${ }^{6} \mathrm{O}$ conhecido trecho diz, "Na ciência como na vida só se acha o que se procura. Não se podem ter respostas quando não se sabe quais são as perguntas" (Evans-Pritchard, 2005: 243). 
somente o Ori. Aquele que você não sabe, só conhece quando você vem e pergunta sobre eles." A resposta de Kolapo foi mais longa e instrutiva. Ao final, disse rindo: "Ori é igual a cálculo avançado. Confundiria principiantes". Resumindo sua explicação, a distância e a infância (no caso, espiritual) teriam limitado o acesso ao conhecimento sobre Ori na diáspora. ${ }^{7}$

Logo no nosso primeiro encontro, os Olodus falaram sobre três tipos de Ori: o Adê, que é o Ori coroado (como o de um presidente, um rei ou rainha), o Ori Odê, que é a cabeça física, e o Ori Inu, ou o Ori interior. Uma vez perguntei se também existe Ori coletivo e os babalaôs responderam que sim, como entre eles, quando estão reunidos no Templo de Ifá. ${ }^{8}$ Comentei com Nílsia em casa que estávamos ficando assim também, com um Ori coletivo do trabalho de campo. Nesse momento chegamos juntas a um insight sobre estarmos ali de fato conhecendo Ori, que não só se apresentava para nós como exagerava na sua revelação, para não deixarmos de lhe dar devido reconhecimento. Como então interpretar aquelas condições de campo, senão por estarmos dando de cara com nosso Ori, no seu caso um Adê? O tema da pesquisa se exibia no próprio exagero das condições de pesquisa. Era como se a magia da etnografia - e não das etnógrafas conduzisse o campo. ${ }^{9}$

Para Nílsia, uma Iyalodè, era isso que acontecia. Se para Evans-Pritchard (2005: 244) "as observações do antropólogo são infletidas por seus interesses teóricos", o que guiava as observações de Nílsia eram os seus interesses espirituais. Com justiça, Evans-Pritchard também falou da necessidade de conhecer o fundamento existencial, para ir além da tradução e entrar no mundo da etnografia. Sendo assim, pode-se dizer que a observação de campo pode ser infletida tanto pela teoria como pela ontologia. Nesse caso, para definir as condições de observação, faz diferença se o fundamento existencial é levado, ou adquirido em campo. Nílsia tinha essa bagagem.

\section{Os festivais-rituais de um ponto de vista privilegiado}

Não restam dúvidas de que residir no palácio durante a pesquisa trouxe conforto e facilidades. Todas as ocasiões em que tive oportunidade de participar dos rituais religiosos nativos, eu era sempre acompanhada de um dos súditos imediatos do Ooni, que me dava o braço ou me segurava pela mão para me conduzir em meio à turba agitada, controlada com violência pelos policiais responsáveis pela guarda da realeza; chegando no templo de destino, ocupava lugar de destaque sempre ao lado de Sua Majestade, com direito a fotos e filmagens. Éramos vistas como parte da realeza, tanto é que em chegando em Lagos, uma jovem atendente de um hotel cinco estrelas no qual nos hospedamos por conta da corte, quando me viu no café da manhã me disse que se sentia muito orgulhosa de me servir e que estava acompanhando minha trajetória pelos noticiários da TV. E eu nem sabia que estava aparecendo na TV. Fiquei surpresa!

\footnotetext{
7 Aqui o paralelo é com outro texto conhecido, o de Anthony Seeger (1980), que compara o etnógrafo a uma criança no mundo.

8 Disseram, "Quando todos se reúnem, como no templo, todos se levantam de uma só vez para saudar Ifá. Todos os Ori que vão para lá rezam, rezam para eles mesmos. Estamos juntos para um mesmo objetivo, [...] Ifá [...] Isso é um Ori coletivo, mas não existe um nome para isso".

9 Outro paralelo, mas invertendo a metáfora de B. Malinowski (1979), que enaltece a magia do etnógrafo para transformar dados em monografia.
} 


\section{A viagem para Lagos}

Por ocasião da proximidade do meu aniversário, o Ooni nos chamou e disse: "Dia 10 de fevereiro se prepare que vamos para cidade de Lagos", mas também como sempre, não disse fazer o quê. Na hora aprazada nos apresentamos no palácio, a movimentação de pessoas era grande, afinal ele só sai em grande comboio. Ele disse que ficaríamos por lá dois a três dias. Na hora de embarcar no carro que seria só para mim e minha orientadora, um belo $S U V$ branco da Mitsubishi, acreditem que se apresentou uma mulher da Jamaica que havíamos visto na noite anterior no palácio, e que se apresentava como Lady Diana. Até aí tudo bem. O triste é que ela chegou no nosso carro mandando-me afastar e me sentar no meio para ela entrar. Mandei que ela se sentasse no meio, e ela dizia "move!" "saia!"). Não deu certo. A viagem que poderia ser pitoresca já começou mal. Lá chegando, por volta de $18 \mathrm{~h}$, todos aguardavam, era uma reunião da nata social de Lagos, assunto de empoderamento das mulheres, só tinha madames, e nós também. Também estava presente o Embaixador do Brasil, o Dr. Flávio Manzanni, hoje exembaixador. Tudo ia muito bem, obrigada. Quando terminou, ao sairmos acompanhadas pelo nosso amigo Olusegun, já entrando no carro, essa mulher pôs ele abaixo de cachorro, humilhou, pintou a ponto dele quase se ajoelhar na rua para ela, se desculpando porque ele nos cumprimentou lá dentro e não a cumprimentou. Mas ele nem a conhecia... Seguimos para um hotel cinco estrelas, com toda pompa e circunstâncias. Eu disse à Deborah, "eu não quero essa mulher acompanhando a gente aqui em Lagos".

Era meu aniversário. Ficamos sabendo que o Ooni retornaria para Ilê Ifé, mas desejei cumprimentá-lo antes de partir e ao sair do quarto para fazer o check-out, fomos chamadas pelos imediatos, porque o Rei estava numa suíte no mesmo andar que a gente, eu não sabia. Seguimos, eu estava toda serelepe com um vestido dois dedos abaixo do joelho e usava um turbante. Quando entramos fui logo repreendida pela minha roupa e porque não usava a tal coroa de Iyalodè. Acreditem, as malas já estavam no carro, foi necessário mandar buscar e troquei de roupa no banheiro social da suíte da Sua Majestade, porque já havia dado meiodia e minha chave já não abria a porta do nosso quarto. Não demorou muito, chegou a jamaicana e ficamos como as três irmãs cajazeiras sentadas diante do Ooni, e ele decidiu que era o dia de destruir essa mulher. Ele queria que eu e minha orientadora ficássemos em Lagos para passear um pouco e nos divertir pelo meu aniversário, disse que ficaríamos no hotel com motorista e que era para eu ir conhecer um dos seus resorts que ficava nessa cidade. Eu não queria ficar mais que um dia. Ele insistiu até que concordei em retornar na quarta-feira de manhã. A jamaicana queria porque queria ficar com a gente. Nesse ponto ficou indigesta a coisa, porque ele disse a ela: "Você não é nenhuma Lady, por acaso você é inglesa? Esse título é concedido a mulheres da Inglaterra" (sendo que foi ele mesmo quem deu o título a ela, e ela acreditou). "Você não passa de uma afro-americana". Humilhou essa criatura até o último limite. Ela chegou a lacrimejar, querendo ficar com a gente, e ele insistia, "você vai atrapalhar as duas, elas têm compromisso aqui e se dão bem". Muito ardiloso, ele se virou para Deborah e perguntou: "Você quer que ela fique com vocês?" Deborah, ainda mais astuta, respondeu "quem deve responder isso é a Iyalodè.” Ele imediatamente fez a pergunta para mim e eu disse: "não é necessário." Minha vingança foi maligna.

Retornaram para Ilê Ifé, e levamos uma pernada dele também, porque o nosso motorista foi embora com a jamaicana e nós ficamos no hall do hotel aguardando pelo motorista de uma advogada, ex-embaixadora da Nigéria em vários 
países da África, que eu nem sabia disso, uma senhora que ele e nós conhecemos na noite anterior, no evento. A princípio disseram que seria a Rainha de Lagos, dona do evento, quem nos receberia; mas ela não apareceu e quem ficou com a gente foi uma Princesa de Lagos, muito simpática, até que o tal motorista chegasse. Isso não foi nada diante do que estava para desenrolar. Quando o motorista chegou num belo carrão, nos despedimos da princesa e embarcamos acreditando que seguiríamos para a residência da tal advogada, mas, para minha surpresa, fomos parar numa big festa top de linha em comemoração ao aniversário de 25 anos de morte de uma senhora da família. Pense numa festa onde as pessoas se vestiam com luxo, seguindo um mesmo tema de cor; era outro lado da Nigéria que não conhecíamos, e eu ostentando aquela coroa com o título de Iyalodè do Rei de Ifé, respeito era pouco claro, afinal uma pessoa da corte naquela festa, creio que para eles também era algo inusitado. Lá também foi comemorado o meu aniversário com parabéns e tudo por mais de cem pessoas. Sorte que tenho fotos, vídeo e um folder sobre a falecida para comprovar isso, porque ninguém acreditaria numa história dessas. Ao final distribuíram presentes, eu ganhei uma toalha de banho e uma maquininha de triturar salsinha. Quando fomos embora, passamos no escritório da advogada, muito simpático, tinha uma secretária simpática, quadros maravilhosos. Nesse escritório nos encontramos com nosso amigo Olusegun, que nos levaria para jantar. Nossa anfitriã nos indicou um respeitável restaurante num hotel de luxo vizinho de sua casa, onde encontramos com um famoso senador do país que havia chegado para jantar, acompanhado de policiais, afinal era semana de eleições. Durante o jantar, Sua Majestade queria saber onde estávamos, e ainda exigiu que fizesse um vídeo do local onde eu estava e enviasse para ele. Só comigo que acontece essas coisas. Nesse vídeo eu até disse I love you ("eu te amo"), escondendo o copo de cerveja é claro!

Seguimos para a casa da doutora e lá nos hospedamos. No dia seguinte nosso amigo veio nos encontrar para dar uma volta pela cidade, fomos até a Ilha de Lagos, não fomos conhecer o tal resort coisa nenhuma e na quarta de manhã retornamos a Ilê Ifé, depois de uma tremenda confusão que o Rei arrumou com a tal princesa com relação ao nosso meio de transporte. Ao fim e ao cabo voltamos num carro Oficial do Palácio que, penso, ficava com essa moça.

Afinal...

Toda vivência do campo tem um potencial etnográfico em si mesmo. O que relatamos da nossa vivência não fazia parte do tema da pesquisa, mas certamente poderia se tornar uma etnografia - e aqui não deixa de ser assim. Para a chamada do dossiê, que diz "Interessa-nos sobretudo discussões sobre a prática do campo - como ele se constrói, ditos e os não-ditos antes e durante o campo, dúvidas, negociações, constituição de relações, localização sociocultural do/a pesquisador/a, relações de poder", só nos resta fazer um arremate final, pois são questões ilustradas por episódios de nossa experiência inusitada, protagonizados pela dublê Iyalodè-Nílsia. Do mesmo modo, o anúncio diz "Buscamos trabalhos que explicitem o fazer antropológico e o cotidiano em campo e coloquem a alteridade, em diferentes sítios, em questão". Tem, no nosso relato, um exemplo em que cotidiano e alteridade - e autoridades - se embaralharam completamente.

De modo diverso ao sentido dado por Clifford Geertz (2008) à parábola das tartarugas sobre tartarugas para se referir à incompletude de toda descrição etnográfica, o deslocamento do nosso foco, do tema de pesquisa para as condições 
do campo, direcionou o movimento descritivo para dentro, apontando para a etnografia da etnografia... Também amplificou a imbricação entre campo e escrita - seguindo a ideia de Marilyn Strathern (1999) de que são, na verdade, dois campos, o de lá e o de cá, constituídos reciprocamente pela antecipação da escrita durante o campo e a recriação do campo durante a escrita. Mostramos um caso em que a trama entre esses dois campos foi adensada pelo inusitado das condições de pesquisa, que expandiu o potencial de produção etnográfica.

Quando no Palácio percebi que estaria integralmente atrelada à Iyalodè, ao Ooni e ao Ori, parei de escrever notas de campo. Decidi viver a minha experiência sem pensar que ali seria depois revivido aqui, nesta escrita acadêmica. Quis me liberar do compromisso intrínseco à situação etnográfica, pretendendo uma inocência antropológica para apenas estar lá. Dei um dos cadernos especiais que tinha levado para Nílsia, que ficou com três. Um ela usou para a pesquisa sobre Ori, outro para a experiência de campo e um mais secreto para detalhes do romance.

Na sala do ora-veja, o sentimento de tédio malinowskiano, a fome e o frio do ar-condicionado me levaram a inventar histórias para crianças, narradas teatralmente, para nos distrair.

\begin{abstract}
Era uma vez, uma moça simples que morava em São José da Lapa. Um belo dia, o rei de um país distante bateu à sua porta e lhe propôs em casamento. Mas impôs uma condição. Teria que deixar tudo, sua casa, família, até seu nome. Em troca seria muito rica e poderosa. Ela sofreu muito até tomar a decisão de seguir o rei. Chegando ao palácio viu que havia outras esposas. "O seu lugar é especial", disse-lhe o rei, "você será minha esposa espiritual". Por sorte, ela havia levado a sua dama de companhia, que lhe dava orientação sentimental e traduzia a fala estranha do rei. Uma madrugada, o rei mandou avisar que iria visitá-la na sua casa no palácio real, que ficava ao lado da casa da esposa número um. Apareceu muitas horas depois, vestido em sua melhor indumentária. Sentou-se no sofá da sala e dispensou a companhia de seu séquito. Passadas várias horas de proposições, elogios e perguntas íntimas, quando o rei exigia que a pajem traduzisse olhando para ele, foi a hora de dizer boa noite. Ele chamou seus escudeiros, virou-se para sair e de repente ficou furioso. Falou bravo em sua língua nativa, levantando uma cadeira e exigindo que fosse retirada imediatamente. Perguntou à pajem quem tinha posto a cadeira ali, mas ela não sabia. Depois desse dia, a rainha brasileira ficou atenta a qualquer mudança introduzida na sua casa. O perigo de feitiço era real. Ela daria tudo para ter a sua vida de plebeia de volta.
\end{abstract}

Retornamos desse mundo de poder, magia e tramas palacianas profundamente impactadas. Nílsia, com toda sua fortaleza, demorou algumas semanas para se readaptar à sua rotina. Ao contrário de mim, que passei os primeiros dias de campo me emocionando à toa - segundo Nílsia, porque eu não estava acostumada àquela carga espiritual - foi quando voltamos para casa que Nílsia não parou de chorar. Nossa volta tinha sido antecipada por dois dias, suficientes para me recuperar de uma malária e conseguir viajar. As eleições tinham sido canceladas e por pouco não ficamos sem acesso ao aeroporto. Mas de verdade já estávamos no nosso limite, querendo voltar de um campo em que a experiência de estar em outro mundo realmente se fez sentir.

De tudo isso, para tirar a moral da história, este exemplo demonstra de maneira exagerada um aspecto incontestável de qualquer trabalho campo: que todos os seus momentos são etnografáveis. Não é possível estabelecer uma divisão a priori entre a vivência de campo e a etnografia, entre condições de pesquisa e resultados da pesquisa. E que nenhuma etnografia é trivial. 
Recebido em 7 de outubro de 2019.

Aceito em 8 de janeiro de 2020.

\section{Referências}

EVANS-PRITCHARD, E. E. Bruxaria, oráculos e magia entre os Azande. Rio de Janeiro, Jorge Zahar. 2005.

GEERTZ, Clifford. A Interpretação das culturas. Rio de Janeiro: Zahar, 2008.

MALINOWSKI, B. Argonautas do Pacífico Ocidental. São Paulo, Abril Cultural. 1979.

SEEGER, Anthony (1980), SEEGER, Anthony. Os índios e nós: estudos sobre sociedades tribais brasileiras. Rio de Janeiro, Campus, 1980.

STRATHERN, M. 1999. Property, substance, and effect: anthropological essays on persons and things. London and New Brunswick, NJ, The Athlone Press. 